\title{
ANALISIS PENGARUH KUALIFIKASI KONTRAKTOR TERHADAP KUALITAS PEKERJAAN PROYEK KONSTRUKSI DI KOTA SEMARANG
}

\author{
Lila Anggraini $^{1}$, Diah Rahmawati ${ }^{2}$,Trias Widorini ${ }^{3}$ \\ ${ }^{1)}$ Jurusan Teknik Sipil Fakultas Teknik Universitas Semarang \\ ${ }^{2)}$ Jurusan Teknik Sipil Fakultas Teknik Universitas Semarang \\ ${ }^{3)}$ Jurusan Teknik Sipil Fakultas Teknik Universitas Semarang
}

\begin{abstract}
The law on construction services has been in effect for seventeen years, but the world of construction services in Indonesia has not been very exciting, especially for construction workers for large-scale and high-tech projects. Indonesia's workforce is still considered not to have capability comparable with foreign construction workforce.

To realize the success of quality buildings and able to function as planned, needed human resources of good quality as well.

And the professional ability of the construction workforce is evidenced by the possession of a skill or skill certificate. As mandated by the Construction Services Act No. 18 of 1999 article 9. that any individual employed by a business entity as a construction planner or supervisor of a particular construction or energy in a construction business enterprise shall have a certificate of expertise.

Based on the research factors that most affect the application of Construction Services Act of 1999 memnai certificate of competence of experts on the implementation of construction work.is a factor of human resources such as education experts, experience, training, age and ownership of certificates. Another factor is the method of implementation of work such as coordination and decision making, while the political factor is the regulation of rules and leadership factors, such as motivation and awards To know how far and how big the role of these construction service experts in achieving the success of construction work, so much in demand by both local and foreign workers, it is deemed necessary to research the role of experts in contributing to the success of a construction work.

Therefore it is necessary to develop further research on the readiness of experts in terms of the fulfillment of the requirements and expertise, in order to obtain the predicate of professional engineers or professional engineers through certification of expertise held by professional associations that followed.
\end{abstract}

\section{Keywords: Certificate of Expert, Competence, Construction Service.}

\section{Pendahuluan}

Keputusan Presiden Republik Indonesia Nomor 80 Tahun 2003 tentang pedoman pengadaan barang/jasa pemerintah, pasal 14 , ayat 10 tertulis bahwa dalam proses prakualifikasi/pascakualifikasi panitia/pejabat pengadaan tidak boleh melarang, menghambat, dan membatasi keikutsertaan calon peserta pengadaan/barang dari luar propinsi/kabupaten/kota lokasi pengadaan barang/jasa. Dengan tidak membatasi keikutsertaan tersebut dapat mengakibatkan kontraktor setempat tidak akan mendapatkan pekerjaan konstruksi, dengan kemampuannya terbatas baik kemampuan modal, peralatan dan personil untuk meningkatkan kualitas pekerjaan. Bila dibandingkan dengan kontraktor yang berasal dari luar propinsi/kabupaten/kota yang pada umumnya lebih unggul memiliki kemampuan modal, keunggulan teknologi, tenaga yang profesional, pengalaman kerja, serta kualitas pekerjaan yang lebih baik.

Demikian juga Peraturan Lembaga Pengembangan Jasa Konstruksi (LPJK) Nomor 03 Tahun 2017 perubahan atas Peraturan Lembaga Pengembangan Jasa Konstruksi (LPJK) Nomor 11 Tahun 2013 tentang Registrasi Usaha Jasa Pelaksana
Konstruksi bagi kontraktor untuk penetapan kualifikasi dan kompetensi usaha jasa pelaksana konstruksi yang dinilai adalah (1) Keuangan yaitu kekayaan bersih dan keamampuan keuangan saat seluruh paket yang dikerjakan; (2) Kemampuan Personalia yaitu Penanggung jawab badan usaha, Penanggung jawab bidang dan penanggung jawab teknik (3) Pengalaman perusahaan.

Kriteria kualitas pada setiap perusahaan tidak sama, demikian pula masing-masing konsumen memiliki kriteria yang berbeda terkait dengan kualitas. Dalam industri jasa konstruksi komponen-komponen yang mendukung kualitas pekerjaan adalah kualifikasi kontraktor yang memilki modal, sumber daya peralatan, sumber daya manusia, dan pengalaman perusahaan

Berdasarkan hasil pengamatan awal, masih ada kesan dari pihak pengguna anggaran/pejabat pembuat komitmen (Pemilik proyek) dan konsultan perencana/pengawas bahwa masih banyak kelemahan pada kontraktor di Kota Semarang dalam menyelesaikan proyek konstruksi seperti Pimpinan perusahaan kurang memiliki pengalaman dan pengertian tentang konstruksi serta tidak memiliki pengetahuan tentang masalah keuangan dan manajemen perusahaan, tingkat pendidikan yang 
kebanyakan tamatan SMU, tidak banyak memiliki modal dasar, tenaga ahli perusahaan tidak memiliki sertifikasi ketrampilan kerja dan sertifikasi keahlian kerja dan sering tidak berada di lokasi proyek, peralatan kerja kurang memadai. Sedangkan dari segi kualitas, waktu pelaksanaan sering terlambat dan hasil pekerjaan sering menyimpang dari spesifikasi teknik yang ditetapkan.

Apabila informasi awal ini benar maka dapat dipastikan bahwa kualitas pekerjaan proyek konstruksi kurang sesuai dengan apa yang diisyaratkan dalam dokumen kontrak dan dokumen lelang terutama spesifikasi teknik.

\section{Kajian Pustaka}

\section{A. Pengertian Manajemen Kualitas}

Dalam industri manufaktur maupun jasa lainnya sering dibicarakan masalah kualitas oleh produsen dan konsumen. Tingkat pemahaman terhadap kualitas sangat beragam tergantung kepada latar belakang serta sudut pandang mereka. Produsen memandang kualitas adalah kepuasan pelanggan (Customer Satisfaction) sedangkan bagi konsumen adalah produk yang dapat memenuhi keinginan dan harapannya.

Kualitas berarti kecocokan/kesesuaian penggunaan produk untuk memenuhi kebutuhan dan kepuasan pelanggan, dimana kualitas yang dijadikan sebagai tolok ukur pada dunia industri. Manajemen perusahaan yang sadar akan kualitas memberikan pelayanan yang terbaik akan terus mencari bentuk peningkatan kualitas

Berbeda dengan industri jasa konstruksi yang memiliki proses unik dan berbeda dengan industri manufaktur. Industri jasa konstruksi lebih mengutamakan ketrampilan sumber daya manusia sedangkan manufaktur melakukan proses mengutamakan alat/mesin didalam mencapai hasil akhir. Sehingga sering diistilahkan " hand made" karena hampir $70 \%$ masih mengandalkan kertampilan manusia. Teori Juran sangat relevan dengan kondisi pelaksanaan proyek karena menekankan pada tiga unsur yang sangat penting dan satu dengan yang saling berkaitan.

\section{B. Manajemen Proyek}

Proyek adalah suatu rangkaian kegiatan yang hanya satu kali dilaksanakan dan umumnya berjangka waktu terbatas, dengan alokasi sumber daya tertentu dan dimaksudkan untuk melaksanakan tugas yang sasarannya telah digariskan dengan jelas. Proyek konstruksi mempunyai sifat sebagai berikut :

1. Memiliki tujuan yang khusus, produk akhir atau hasil kerja akhir.

2. Jumlah biaya, sasaran jadwal serta kriteria mutu dalam proses mencapai tujuan yang telah ditentukan

3. Bersifat sementara, dalam arti umumnya dibatasi oleh selesainya tugas dari awal dan akhir ditentukan dengan jelas.

4 Tidak berulang,jenis dan intensitas kegiatan berubah sepanjang proyek berlangsung

\section{Karakteristik Kontraktor}

Kemampuan suatu organisasi perusahaan dalam menentukan posisi untuk meraih kesuksesan, tergantung pengelolaan dan karakter sumber daya yang dimiliki kontraktor sebagai keunggulan kompetitif dalam meningkatakn kualitas perusahaan. Karakteristik suatu organisasi akan memberikan efek persaingan dalam memenangkan persaingan bisnis yang merupakan jawaban dalam pengembangan suatu bentuk usaha. Menurut Lembaga Pengembangan Jasa Konstruksi (LPJK) Nomor 10 Tahun 2013, menerangkan bahwa karakteristik kontraktor yang berkaitan dengan kualifikasi bentuk badan usaha dalam meregistrasikan kembali badan usaha yang melaksanakan usaha jasa konstruksi

\section{Penggolongan Kualifikasi Badan Usaha}

Penggolongan kualifikasi usaha jasa konstruksi dibagi dalam 3 (tiga) kualifikasi yaitu:

1. Kualifikasi K (Kecil), kontraktor kualifikasi usahakecil terdiri dari :
a. Kualifikasi K-1
b. Kualifikasi K-2
c. Kualifikasi K-3

2. Kualifikasi M (Menengah)
a. Kualifikasi M-1
b. Kualifikasi M-2

3. Kualifikasi B (Besar)

a. Kualifikasi B-1

b. Kualifikasi B-2

\section{E. Penilaian Kelayakan Badan Usaha}

Dalam Perlem LPJK Nomor 6 Tahun 2014 penggolongan kualifikasi badan usaha jasa pelaksana konstruksi didasarkan pada kriteria tingkat kompetensi dan potensi kemampuan usaha terdiri kecil, menengah dan besar, kemampuan melaksanakan pekerjaan berdasarkan kriteria resiko dan kriteria penggunaan teknologi.

Dapat dijelaskan dalam tabel berikut

1. Data Keuangan Badan Usaha

Tabel 1. Kemampuan Keuangan (KB) Jasa Pelaksana

\begin{tabular}{cc}
$\begin{array}{c}\text { Kualifikasi Badan } \\
\text { Usaha }\end{array}$ & Kekayaan Bersih \\
\hline $\mathrm{P}$ & $\geq 50 \mathrm{Jt}$. \\
$\mathrm{K}-1$ & $>50 \mathrm{~s} / \mathrm{d} .200 \mathrm{Jt}$. \\
$\mathrm{K}-2$ & $>200 \mathrm{~s} / \mathrm{d} .350 \mathrm{Jt}$. \\
$\mathrm{K}-3$ & $>350 \mathrm{~s} / \mathrm{d} .500 \mathrm{Jt}$. \\
M-1 & $>500 \mathrm{~s} /$ d. $2 \mathrm{Mly}$. \\
M-2 & $>2 \mathrm{~s} /$ d. $10 \mathrm{Mly}$. \\
B-1 & $>10 \mathrm{~s} / \mathrm{d} .50 \mathrm{Mly}$. \\
B-2 & $\geq 50 \mathrm{Mly} . \infty \mathrm{Mly}$. \\
\hline
\end{tabular}

2. Data Tenaga Kerja

Tabel 2. Kecukupan Tenaga Kerja Jasa Pelaksana

\begin{tabular}{|c|c|c|c|}
\hline Kualifikasi & PJBU & PJT & PJK \\
\hline $\mathrm{P}$ & \multicolumn{2}{|c|}{1 SKTK Tk.I. } & \multirow{3}{*}{$\begin{array}{l}\text { Boleh } \\
\text { dirangkap }\end{array}$} \\
\hline K-1 & \multirow{2}{*}{\multicolumn{2}{|c|}{$\begin{array}{lll}1 & \text { SKTK } & \text { Tk.III. } \\
1 & \text { SKTK } & \text { Tk.II. }\end{array}$}} & \\
\hline $\mathrm{K}-2$ & & & \\
\hline
\end{tabular}




\begin{tabular}{|c|c|c|c|}
\hline Kualifikasi & PJBU & PJT & PJK \\
\hline K-3 & \multicolumn{2}{|c|}{1 SKTK Tk.I. } & PJBU / PJT \\
\hline M-1 & \multirow{2}{*}{$\begin{array}{c}\text { PJBU } \\
\text { terpisah } \\
\text { dengan } \\
\text { PJT / PJK }\end{array}$} & $\begin{array}{l}1 \text { org. ber- } \\
\text { SKA } \\
\text { Muda }\end{array}$ & \multirow{2}{*}{$\begin{array}{c}1 \text { org. ber- } \\
\text { SKA setara } \\
\text { PJT, boleh } \\
\text { merangkap } 2 \\
\text { Klasifikasi } \\
\text { berbeda }\end{array}$} \\
\hline M-2 & & $\begin{array}{c}1 \text { org. ber- } \\
\text { SKA } \\
\text { Madya }\end{array}$ & \\
\hline B-1 & \multirow[t]{2}{*}{$\begin{array}{c}\text { PJBU } \\
\text { terpisah } \\
\text { dengan } \\
\text { PJT / PJK }\end{array}$} & $\begin{array}{l}1 \text { org. ber- } \\
\text { SKA } \\
\text { Madya } \\
\text { selama } 3 \\
\text { th. }\end{array}$ & \multirow[t]{2}{*}{$\begin{array}{c}1 \text { org PJK } \\
\text { untuk setiap } \\
\text { Klasifikasi } \\
\text { dengan SKA } \\
\text { setara dengan } \\
\text { PJT }\end{array}$} \\
\hline B-2 & & $\begin{array}{c}1 \text { org. ber- } \\
\text { SKA } \\
\text { Madya } \\
\text { selama } 6 \\
\text { th. }\end{array}$ & \\
\hline
\end{tabular}

3. Data Pengalaman

Tabel 3. Kemampuan Menangani Paket Pekerjaan

\begin{tabular}{|c|c|c|}
\hline Kualifikasi & \multicolumn{2}{|c|}{$\begin{array}{c}\text { Kemampuan } \\
\text { Menangani Pekerjaan }\end{array}$} \\
\hline $\mathrm{P}$ & $\begin{array}{c}0 \mathrm{~s} / \mathrm{d} .300 \\
\mathrm{Jt} .\end{array}$ & 1 \\
\hline $\mathrm{K}-1$ & $\begin{array}{l}300 \text { s/d. } 1 \\
\text { Mily. }\end{array}$ & 5 \\
\hline $\mathrm{K}-2$ & $\begin{array}{l}1 \text { s/d. 1,75 } \\
\text { Mily. }\end{array}$ & 5 \\
\hline $\mathrm{K}-3$ & $\begin{array}{l}1,75 \text { s/d. } \\
2,50 \text { Mily. }\end{array}$ & 5 \\
\hline M-1 & $\begin{array}{l}2,50 \text { s/d. } 10 \\
\text { Mily. }\end{array}$ & $\begin{array}{c}6 @ 1,2 \\
\mathrm{~N}\end{array}$ \\
\hline M-2 & $\begin{array}{l}2,50 \text { s/d. } 50 \\
\text { Mily. }\end{array}$ & $\begin{array}{c}6 @ 1,2 \\
\mathrm{~N}\end{array}$ \\
\hline B-1 & $\begin{array}{l}2,50 \text { s/d. } \\
250 \text { Mily. }\end{array}$ & $\begin{array}{c}6 @ 1,2 \\
\mathrm{~N}\end{array}$ \\
\hline B-2 & $\begin{array}{l}\text { Tidak } \\
\text { terbatas }\end{array}$ & $\begin{array}{c}6 @ 1,2 \\
\mathrm{~N}\end{array}$ \\
\hline
\end{tabular}

\section{F. Proses Pengadaan Jasa Konstruksi}

Dalam proses pengadaan jasa konstruksi sebagaimana diatur dalam undang- undang Jasa Konstruksi serta Peraturan Pelaksanaannya, dan Keputusan Presiden No. 80 Tahun 2003, serta Keputusan Presiden No. 61 Tahun 2004, Peraturan Presiden No. 32 Tahun 2005 tentang perubahan kedua, Peraturan Presiden No.70 Tahun 2005 tentang perubahan ketiga dan Keputusan Presiden No. 8 Tahun 2006 tentang perubahan ke empat atas Keputusan Presiden Nomor 83 Tahun 2003 tentang pedoman pelaksanaan pengadaan barang/jasa pemerintah, maka ketentuan tentang persyaratan penyedia jasa konstruksi dan penentuan metode pemilihan penyedia jasa konstruksi adalah sebagai berikut:

\section{G. Analisis Faktor}

Analisis faktor merupakan salah satu teknik analisis statistik Multivariate yang bertujuan untuk mereduksi data. Proses analisis faktor digunakan untuk menemukan hubungan antara variable yang saling independen yang kemudian dikelompokkan menjadi beberapa kelompok, sehingga bias terbentuk satu atau beberapa kumpulan variabel yang lebih sedikit dari jumlah variabel awal.

Tahapan dalam analisis faktor adalah sebagaiberikut :

1) Memilih variabel yang layak untuk analisis faktor

2) Menyusun variabel

3) Merotasi kelompok faktor

4) Menamakan kelompok faktor

\section{H. Korelasi Kualifikasi Kontraktor dan Kualitas Pekerjaan}

Korelasi karakteristik kontraktor dengan kualitas pekerjaan merupakan korelasi dua variabel yang saling terkait dan saling mempengaruhi, oleh karena itu untuk mengetahui korelasi antar dua variabel dilakukan dengan menggunakan STATISTIK.

Uji Validitas, Reliabilitas dan Hasil Analisis Validitas

Suatu instrumen pengukuran dikatakan valid jika instrumen dapat mengukur sesuatu dengan tepat apa yang hendak diukur. Uji validitas dilakukan dengan teknik korelasi yaitu mengkorelasikan skor setiap butir dengantotal variabel tersebut dengan menggunakan korelasi Product Momen dengan rumus sebagai berikut :

$$
\text { rhitung }=\frac{n\left(\sum X Y\right)-\left(\sum X\right) \cdot\left(\sum Y\right)}{\sqrt{\left\{n \cdot \sum X^{2}-\left(\sum X\right)^{2}\right\}\left\{n \cdot \sum Y^{2}-\left(\sum Y\right)^{2}\right\}}}
$$

Dimana :

rhitung $=$ Koefisien Korelasi

$\mathrm{X} \quad=$ Variabel Bebas

$\mathrm{Y} \quad=$ Variabel Terikat

$\mathrm{n} \quad=$ Jumlah Responden

Korelasi PPM dilambangkan (r) dengan ketentuan nilai $\mathrm{r}$ tidak lebih dari harga $(-1 \leq \mathrm{r} \leq+1)$. Apabila nilai $r=-1$ artinya korelasinya negatif sempurna dan jika $\quad \mathrm{r}=0$ artinya tidak ada korelasi dan $r=1$ berarti korelasinya sangat kuat.

Selanjutnya untuk mencari makna hubungan variable $\mathrm{X}$ terhadap $\mathrm{Y}$ maka hasil korelasi PPM tersebut dihitung dengan Uji-t dengan rumus :

$$
\text { thitung }=\frac{r \sqrt{n-2}}{\sqrt{1-r^{2}}}
$$

Dimana :

thitung = Nilai $\mathrm{t}$

$\mathrm{r} \quad=$ Nilai koefisien korelasi

$\mathrm{n} \quad=$ Jumlah sampel

Distribusi (Tabel t) untuk ó $=0,05$ dan derajat kebebasan $(\mathrm{dk}=\mathrm{n}-2)$ Kaidah keputusan : Jika $\mathrm{t}$ hitung $>\mathrm{t}$ tabel berarti valid sebaliknya $\mathrm{t}$ hitung $<\mathrm{t}$ tabel berarti tidak valid

Reliabilitas

Reliabilitas menunjukkan pada tingkat kehandalan sesuatu yang dapatdipercaya dandapat dihandalkan dengan 
menggunakan metode Alpha Cronbach's. Rumus reliabilitas dengan metode Alpha Cronbach's adalah :

$$
R_{11}=\left[\frac{k}{k-1}\right]\left[1-\frac{\sum \sigma_{b}^{2}}{\sigma_{1}^{2}}\right]
$$

Dimana :

$\mathrm{R} 11=$ Reliabilitas Instrumen

$\mathrm{K}$ = Banyaknya butir pertanyaan

$\sum \sigma_{b}^{2}=$ Jumlah varian butir

Uji signifikasi dilakukan pada taraf signifikasi 0,05 , artinya instrumen dapat dikatakan reliabel bila nilai alpha lebih besar dari $r$ kritis product moment.

Hasil Analisis

Penafsiran atas hasil penelitian terhadap hasil analisa data dilakukan untuk mendapatkan informasi lebih jauh yang berkaitan dengan hasil penelitian. Selain itu interprestasi juga dimaksudkan untuk mendapatkan informasi yang relevan dengan hasil penelitian. Interprestasi yang dilakukan adalah cara terbatas berdasarkan data dan hubungannya dengan penelitian serta dilaksanakan pada saat bersamaan

\section{III.Metode Penelitian}

\section{A. Rancangan Penelitian}

Metode yang menjelaskan bahwa penelitian ditinjau dari hadirnya variabel saat terjadinya, serta menjelaskan variable masa lalu dan sekarang disebut metode diskriptif yang artinya menggambarkan atau membeberkan sehingga metode ini tepat digunakan untuk meneliti status sekelompok manusia, perusahaan sebagai obyek penelitian, yang bertujuan membuat deskriptif gambaran secara sistimatis, faktual dan akurat mengenai fakta-fakta serta hubungan antar fenomena yang diselidiki, (Riduwan,2004).

Tempat Penelitian

Penelitian ini bertempat di Kota Semarang, yaitu Asosiasi Jasa Konstruksi (Gapensi, Aksi, Garansi, Aspekindo dan Gapeksindo Jenis dan Sumber Data Jenis Data

Untuk mendapatkan tujuan akhir dari penelitian, maka data utama yang diperlukan adalah data-data data tenaga ahli, baik bersertifikat maupun tidak, data pengalaman kerja dalam proyek konstruksi.

1) Data primer

Yaitu data yang diperoleh dari responden dengan mendistribusikan koesioner atau wawancara langsung kepada kontraktor, dan pemilik proyek.

2) Data sekunder

Data sekunder diperoleh dari literatur-literatur dan media yang berhubungan langsung dengan obyek yang diteliti.
B. Kerangka Analisa



\section{IV.HASIL DAN PEMBAHASAN}

Dari penelitian diatas maka didapat analisis sebagai berikut :

1) Faktor 1, terdiri dari variabel tenaga teknik yang kurang memahami spesifikasi teknik dan gambar kerja, variabel modal yang cukup untuk membiayai proyek yang dikerjakan, variabel kontraktor mengalami kesulitan keuangan saat melaksanakan proyek, variabel kontraktor kesulitan mempekerjakan tenaga administrasi, variabel kontraktor kesulitan mempekerjakan tenaga teknik $\mathrm{S} 1$, variabel mengalami kesulitan dalam pengajuan termin, variabel modal proyek diperoleh dari pinjaman bank, variabel tenaga teknik memahami pembuatan laporan, variabel kesulitan mempekerjakan tenaga teknik STM dan D3, variabel mengasuransikan tenaga kerja,variable tenaga teknik penuh waktu selalu ada dilokasi proyek, variabel tenaga teknis yang ditempatkan 
sama seperti dokumen kontrak. Faktor ini diberi nama faktor sumber daya manusia dan modal kontraktor.

2) Faktor 2 terdiri dari variabel menunjukkan bukti pelunasan pajak, variabel panitia melakukan proses tender dengan benar, variable mematuhi persyaratan prosestender, variable mengikuti spesifikasi teknis dalam pelaksanaan proyek, variabel menunjukkan dokumen asli pada proses tender, variabel menyelesaikan proyek tepat waktu, variabel memulai pekerjaan tepat waktu, variabel membuat shop drawing setiap item pekerjaan, variabelmenyediakan standar keselamatan \& kesehatan. Faktor ini diberi nama faktor legal dan administrasi.

3) Faktor 3 terdiri dari variabel memiliki peralatan sendiri pada pelaksanaan proyek, variabel pengetesan material yang digunakan di proyek. Faktor ini diberi nama faktor peralatan.

Dari 3 ( tiga ) faktor baru yang terbentuk dengan nilai total varians kumulatif sebesar $81,856 \%$, factor utama yang mempengaruhi kualitas pekerjaan kontraktor terdapat pada kelompok I ( faktor sumber daya manusia dan modal kontraktor) dengan nilai eigen sebesar 7,708 dan nilai keragaman total sebesar 57,138 $\%$, yang terdiri dari variable :

a. Tenaga teknik yang kurang memahami spesifikasi teknik. Di samping memiliki pengatahuan tentang teknik, tenaga teknik perlu juga memiliki pengalaman kerja yang memahami spesifikasi teknik, gambar kerja, sehingga tidak terjadi penyimpangan yang berakibat perbaikan dan berkurangnya kualitas pekerjaan pada saat pelaksanaan proyek.

b. Modal yang cukup untuk membiayai proyek yang dikerjakan.Dengan modal yang cukup maka kontraktor dapat membiayai proyek yang dikerjakan dimana bahan yang diperlukan dan upah bisa dibayarkan sehingga dapat menjaga kualitas pekerjaan dan melancarkan pelaksanaan pekerjaan.

c. Kontraktor mengalami kesulitan keuangan saat melaksanakan proyek Kesulitan keuangan sangat berpengaruh terhadap kualitas pekerjaan karena dapat menghambat keperluan material, upah tenaga kerja dan operasional perusahaan, sehingga kemungkinan kontraktor tidak bisa menyelesaikan pekerjaan tepat waktu.

d. Kontraktor kesulitan mempekerjakan tenaga administrasi

Kesulitan mempekerjakan tenaga administrasi dapat mempengaruhi kualitas pekerjaan karena tenaga administrasi juga memiliki peranan yang besar dalam menunjang operasional kontraktor sehingga dapat meningkatkan kinerja kontraktor dan bisa menyelesaikan pekerjaan tepat waktu.

e. Kontraktor kesulitan mempekerjakan tenaga teknik S1.Faktor tenaga teknik yang berpendidikan S1 perlu diperhatikan oleh perusahaan, di samping pengatahuan tentang keteknikan dan pengalaman yang memahami akan spesifikasi teknik, gambar kerja, sehingga diharapkan dapat menjaga kualitas pekerjaan dan tidak terjadi penyimpangan yang berakibat perbaikan atau pengulangan pekerjaan yang berakibat pembengkakan biaya dan perpanjangan waktu penyelesaian pekerjaan.

f. Mengalami kesulitan dalam pengajuan termin. Kesulitan dalam proses pengajuan termin oleh pengguna jasa terhadap kontraktor pelaksana berdampak pada ketepatan waktu dalam proses penyelesaian pekerjaan. Artinya, cepat lambatnya proses pencairan termin akan berpengaruh langsung pada proses penyelesaian pekerjaan.

g. Modal proyek diperoleh dari pinjaman bank. Modal sangat berpengaruh terhadap kualitas pekerjaan karena keuangan merupakan salah satu faktor yang dapat memperlancar pekerjaan dan meningkatkan kinerja kontraktor sehingga bisa menyelesaikan pekerjaan tepat waktu.

h. Tenaga teknik memahami pembuatan laporan. Pemahaman pembuatan laporan teknis dan melaporkan tepat waktu mempengaruhi kinerja kontraktor karena pelaporan yang benar dan tepat waktu menyebabkan pembayaran terhadap pekerjaan yang sudah dilaksanakan dapat dilakukan dengan cepat dan mengurangi resiko kelebihan pembayaran.

i. Kesulitan mempekerjakan tenaga teknik STM dan D3 .Faktor tenaga teknik yang berpendidikan STM dan D3 perludiperhatikan oleh perusahaan, di samping pengatahuan tentang keteknikan dan pengalaman yang memahami akan spesifikasi teknik, gambar kerja, sehingga diharapkan dapat menjaga kualitas pekerjaan.

j. Mengasuransikan tenaga kerja. Asuransi tenaga kerja perlu diperhatikan dalam pelaksanaan proyek, sehingga apabila terjadi kecelakaan pada saat pelaksanaan proyek tenaga kerja dapat dibiayai oleh asuransi kecelakaan tenaga kerja.

k. Selalu menempatkan Tenaga teknik penuh waktu pada pelaksanaan proyek. Faktor tenaga teknik penuh waktu benar-benar harus diperhatikan pada pelaksanaan proyek, karena berhasil tidaknya suatu pekerjaan tergantung dari tenaga teknik yang mengatur dan membimbing para pekerja pada pelaksanaan proyek sehingga dapat menghasilkan pekerjaan yang bermutu baik dan penyelesiaian tepat waktu.

1. Tenaga teknis yang ditempatkan sama seperti dokumen kontrak. Faktor penempatan tenaga teknis yang sesuai sangat berpengaruh karena dengan keahlian yang sesuai dengan jenis pekerjaan yang dilaksanakan dapat meningkatkan kualitas pekerjaan.

Faktor kedua yang berpengaruh terhadap kualitas pekerjaan kontraktor yaitu ada pada kelompok II (factor legal dan administrasi) dengan nilai eigen sebesar 1,451 dan nilai keragaman total sebesar 5,804 $\%$, yang terdiri dari variabel menunjukkan bukti 
pelunasan pajak, variabel panitia melakukan proses tender dengan benar, variabel mematuhi persyaratan proses tender, variabel mengikuti spesifikasi teknis dalam pelaksanaan proyek, variable menunjukkan dokumen asli pada proses tender, variable menyelesaikan proyek tepat waktu, variable memulai pekerjaan tepat waktu, variable menyediakan standar keselamatan \& kesehatan.

Faktor ketiga yang mempengaruhi kualitas pekerjaan kontraktor terdapat pada kelompok III ( faktor peralatan) dengan nilai eigen sebesar 1,305 dan nilai keragaman total sebesar 5,220\%, yang terdiri dari variabel memiliki peralatan sendiri pada pelaksanaan proyek, variable pengetesan material yang digunakan di proyek.

\section{Kesimpulan dan Saran}

\section{A. Kesimpulan :}

Berdasarkan hasil penelitian terhadap karakteristik kontraktor, korelasi antara kualifikasi dengan kualitas pekerjaan kontraktor, dan faktor yang mempengaruhi kualitas pekerjaan pada pelaksanaan proyek di Kota Semarang, dapat disimpulkan sebagai berikut:

1) Faktor utama yang mempengaruhi kualitas pekerjaan kontraktor terdapat pada kelompok I (faktor sumber daya manusia dan modal kontraktor) karena kelompok faktor ini sebagai penyumbang terbesar terhadap seluruh varian ( Eigenvalues sebesar 7,708 dan nilai keragaman total sebesar $57,138 \%$ ) yang terdiri dari : variable tenaga teknik yang kurang memahami spesifikasi teknik dan gambar kerja, variable modal yang cukup untuk membiayai proyek yang dikerjakan, variabel kontraktor mengalami kesulitan keuangan saat melaksanakan proyek, variabel kontraktor kesulitan menempatkan tenaga administrasi, variabel kontraktor kesulitan menempatkan tenaga teknik S1, variable mengalami kesulitan dalam pengajuan termin,variable modal proyek diperoleh dari pinjaman bank, variabel tenaga teknik memahami pembuatan laporan, variable kesulitan menempatkan tenaga teknik STM dan D3, variabel mengasuransikan tenaga kerja, variable tenaga teknik penuh waktu selalu ada di lokasi proyek, variabel tenaga teknis yang ditempatkan sama seperti dokumen kontrak.

2) Korelasi kualifikasi kontraktor dengan kualitas pekerjaan diuraikan sebagai berikut:

a. Pada kontraktor kualifikasi K_1 variabel pengalaman jenis pekerjaan yang dikerjakan oleh kontraktor dengan nilai korelasi sebesar 0,543 , variabel penanggung jawab badan usaha dengan nilai korelasi sebesar 0,585, variabel pengalaman tenaga kerja dengan nilai korelasi sebesar 0,514 berpengaruh signifikan terhadap kualitas pekerjaan. Sedangkan tingkat hubungan yang terjadi adalah positif. b. Pada kontraktor kualifikasi K_2 variabel jenis proyek yang dilakukan dengan nilai korelasi sebesar 0,479, variabel penanggung jawab badan usaha dengan nilai korelasi sebesar 0,589, variabel pengalaman tenaga kerja (X17) dengan nilai korelasi sebesar 0,434 berpengaruh signifikan terhadap kualitas pekerjaan. Sedangkan tingkat hubungan yang trjadi adalah positif.

c. Pada kontraktor kualifikasi K_3 variabel jenis proyek yang dilakukan dengan nilai korelasi sebesar 0,219, variabel penanggung jawab badan usaha dengan nilai korelasi sebesar 0,242, variabel pengalaman tenaga kerja (X17) dengan nilai korelasi sebesar 0,263 memiliki hubungan dengan kualitas pekerjaan.

d. Pada kontraktor kualifikasi M variabel pengalaman jenis pekerjaan yang dikerjakan oleh kontraktor dengan nilai korelasi sebesar 0,834 , variabel pengalaman tenaga kerja dengan nilai korelasi sebesar 0,546 berpengaruh signifikan terhadap kualitas pekerjaan. Sedangkan tingkat hubungan yang terjadi adalah positif.

\section{B. Saran-Saran}

Berdasarkan pada kesimpulan diatas, makas aran-saran yang dapat disampaikan adalah sebagai berikut :

1 Untuk meningkat daya saing kontraktor Kualifikasi $\mathbf{M}$ kebawah perlu meningkatkan kualifikasi pendidikan dan pengalaman tenaga kerjanya.

2 Untuk meningkatkan kualitas pekerjaan kontraktor perlu ditingkatkan faktor kualitas sumber daya manusia dan modal kontraktor yang mempengaruhi kualitas pekerjaan.

Penelitian ini dapat dikembangkan lagi untuk mengetahui karakteristik keseluruh kontraktor di Kota Semarang

\section{DAFTAR PUSTAKA}

Alwi, S, Manajemen Sumber Daya Manusia Strategi Keunggulan Kompetitif, Edisi Pertama, Penerbit BPPE,Yogjakarta, 2001

Arikunto, S, Manajemen Penelitian, Cetakan ketujuh, PT. Asdi Mahasatya, Jakarta, 2005.

Abrar Husen, Manajemen Proyek, Edisi Revisi, Penerbit Andi, 2009.

Ervianto, W. I. Manajemen Proyek Konstruksi, Penerbit ANDI, 2005.

Undang-undang RI Nomor 18 Tahun 1999, Tentang Jasa Konstruksi. Departemen Pekerjaan Umum: Penerbit PT. Mediatama Saptakarya.

Keputusan Menteri Permukiman dan Prasarana Wilayah, Nomor 257/KPTS/M/2004, Tentang Standar dan Pedoman Pengadaan Jasa Konstruksi.

Kepres RI No. 80 Tahun 2003, Tentang Pedoman Pelaksanaan Pengadaan Barang/Jasa 
Pemerintah.Beserta Penjelasannya.Bandung: Penerbit Citra Umbara.

Peraturan Lembaga Pengembangan Jasa Konstruksi Nomor : 11 Tahun 2006, Tentang Registrasi Usaha Jasa Pelaksana Konstruksi. Jakarta.

Peraturan Lembaga Pengembangan Jasa Konstruksi Nomor : 10 Tahun 2013, Tentang Registrasi Usaha Jasa Pelaksana Konstruksi. Jakarta

Peraturan Lembaga Pengembangan Jasa Konstruksi Nomor : 6 Tahun 2014, Tentang Registrasi Usaha Jasa Pelaksana Konstruksi. Jakarta

Sambas Ali Muhidin, Analisis Korelasi, Regresi dan Jalur dalam Penelitian,Penerbit Pustaka Setia, Bandung, 2001 